\title{
Humanitarian knowledge in the context of the media landscape
}

\author{
Svetlana E. Rudneva ${ }^{1 *}$ \\ ${ }^{1}$ Financial University under the Government of the Russian Federation, Department of Humanities, \\ Moscow, Russia
}

\begin{abstract}
The article deals with the issues of the humanitarian education system in the information society. The initial prerequisites are the spread of a technocratic approach to determining priorities in education, professional development of personnel, based on new strategies aimed at training a specialist, who has a high degree of knowledge of information technologies but does not have a general humanitarian culture. This situation can lead to negative civilisational implications over time because scientific and technological progress without considering the cultural component can cause moral and spiritual regression. The article substantiates the important role of humanitarian education in the system of fundamental education. Humanitarian education is perceived as a set of knowledge about the history, development patterns of human civilisation, showing the intellectual level of human society, its self-consciousness, the need for a holistic approach to studying human beings and the world around them. Humanitarian education should ensure the formation of moral consciousness, the worldview, and the life stance of the individual, his qualities, beliefs, and motives of activity. When preparing the article, the authors used the analysis and synthesis method, as well as a method of systematisation of the empirical and theoretical data available on the topic under consideration. The outcomes of the conducted research, their scientific novelty, consist in identifying humanitarian education priorities in the current context, its role in forming ideas about values, and the individual's worldview. As stated in the article, the main task of humanitarian education is to create conditions for forming an individual's worldview, moral consciousness, life stance, beliefs, motives, and to develop his qualities.
\end{abstract}

Keywords: humanitarian knowledge, humanitarian education, upbringing, molding of personality.

\section{Introduction}

The main tasks of humanitarian education are forming the basic values of new generations in the moral dimension, transferring them scientific knowledge and ideas. The most important component of fundamental education, in general, is humanitarian knowledge, which allows forming a genuine person with broad views on the world, human, and nature, rather than narrowly trained professional. The following features have traditionally distinguished

\footnotetext{
*Corresponding author: $\underline{\text { se rudneva@mail.ru }}$
} 
Russian education: the humanitarian component, orientation to broad enlightenment, patriotism, and democracy.

The focus on a technocratic approach to education and professional development of the staff contributes to the fact that the education system trains a specialist who possesses high information technologies but lacks a common humanitarian culture. This can cause negative civilisational implications in the future because scientific and technological progress can lead to moral and spiritual regression. The technocratic approach involves not only the unification and standardisation of industrial goods, but also the "massification of consciousness", worldview, and personal values. In contrast, the humanitarian approach allows ensuring the uniqueness of the individual in everything, its originality, including educational and upbringing socio-cultural activities. Molding a personality as a humanitarian, spiritual and moral, value-oriented process should be carried out in advance, have a deep basic character. This approach allows preventing the dominance of mass culture, saving people against the manifestations of barbarism on the part of human society in politics, economy, international relations, and ecology.

\section{Methods}

When preparing the article, the authors used the analysis and synthesis methods, as well as a method of systematisation of the empirical and theoretical data available on the topic under consideration.

People have stopped treating humanitarian knowledge as something unnecessary, meaningless, and coming up with an awareness of the critical role of the humanitarian component in the system of training specialists in higher professional education programs. Since the growing dominance of the information society, understanding that it is impossible to maintain the country's necessary level of civilisation without knowledge of history, literature, and languages increases. Otherwise, the people will turn into a shapeless, disordered community of producers and consumers.

Humanitarian education is based on the following main principles: humanitarian knowledge is a system of knowledge about the history of human civilisation, its development patterns that determine the intellectual level of human society, its level of self-consciousness, as well as a holistic approach to the study of human society and the surrounding world [1]. Humanitarian education aims at forming an individual who understands the status and dynamics of culture [2]. Humanitarian education should ensure the solution of its main task, which consists in creating prerequisites for the development of a social worldview, the life stance of the individual, forming his moral consciousness, beliefs, motives, and qualities [3].

A person's spirituality is formed in the course of mastering the humanitarian knowledge values and realising its important role. At present, the need to study disciplines that provide tools for a person to get acquainted with a huge information flow becomes more acute. A person needs to be trained so that he could get acquainted with such an information flow, systematise and generalise it, find criteria that would allow searching quickly for reliable sources of the needed knowledge. The education system should provide students with such criteria. It is well known that at present people are faced with excessive information, which includes a lot of junk information. Besides, sometimes certain information is distributed to manipulate the human consciousness [4]. Therefore, those who do not want to be completely misinformed by such a flow of unreliable facts and deliberately misled need to master a kind of art of information perception. This is a very complicated task, which cannot be solved based just on common sense and intuition. Only teaching of the humanities can help to acquire such skills. For objective reasons, this determines the high demand for the humanities and their study in the near future. The modern education system should provide people with opportunities for their full self-actualisation in an ever-more becoming complex world [5]. 
Currently, the fundamental values of humanitarian education are changing. Because the importance of sciences aimed at creating new technical devices that fundamentally transform production, everyday life, and ways of transmitting information is constantly increasing, there is a danger that the importance of expanding knowledge that allows studying the patterns of interaction of individuals in small and large communities, as well as the inconsistency of socio-political, economic, and socio-cultural changes that arise in the context of the rapidly globalising world is being underestimated. In many countries of the world, funding of universities that train specialists in the humanities is declining, and the employment of graduates who majored in such previously popular areas of training is becoming more complicated [6]. In the current context, it is necessary to review the very content of humanitarian education and to expand the scope of its use.

The main reference points for Russian education are the qualities of the individual, the holistic nature of education based on subjective ways of mastering culture. At present, the pedagogical practice should overcome the emerging alienation of young people from education. This concerns those who are not involved in the educational process and underestimate the importance of education in their lives. Only education in the humanities that focuses on a specific individual can help overcome such problems [6].

Humanitarian education is based primarily on humanitarian knowledge, covering the value attitude to the reality under consideration. All knowledge objects are studied from the standpoint of morality, culture, religion, and aesthetics. Humanitarian knowledge deals with the problems of the meaning of human life, uncovering the meaning of a fact, the value of a thing. Humanitarian cognition is the awareness of human existence in terms the valuesemantic stances. This cognition represents the unity of value and verity, meaning and fact; it reveals how scientific knowledge aims at solving human problems. Humanitarian knowledge includes a person and his culture, it is conditioned by the fact that the human being belongs to a certain sphere of reality - human nature [7].

Meaningful humanitarian education is the starting point of the individual's knowledge mastering process and comprehending their education. In the course of receiving a humanities education, the context of life and the relationships between people are considered in the aggregate as a whole. It is them that act as a structural element of humanitarian knowledge and determine its nature. Awareness of the experience of people's relationships allows creating and considering a system of internal relationships of the individual [8].

A systemic factor that gives any subject a super-subjective character is a focus on humanitarian knowledge, which contributes to forming universal skills when acquiring humanitarian knowledge [9]. The substantive affiliation of humanitarian knowledge, such as history, literature, languages, etc., does not act as its fundamental factor. The main thing is the awareness of the humanities as an imminent, implicit structure that turns the phenomenon into a multicomponent, super-subjective, integral entity. Super subjectivity is expressed in language and culture, so the humanities are based on a culture that does not exist outside of the language, whose native speaker is a human [9]. A human unites the world of culture and the world of language by interconnections. Language makes it possible to preserve culture. People preserve and communicate culture from generation to generation. Culture represents the main human-forming factor in the content of education [10].

A unified approach to teaching different subjects is necessary to achieve the common goals of humanitarian education. This approach is possible based on consideration of worldview issues using humanitarian knowledge, which allows ensuring meaningful and worldview coordination of curriculum in the education system [9]. 


\section{Results}

Addressing worldview issues based on standard approaches and goals in teaching certain subjects is possible only using humanitarian knowledge, which serves a meaningful and worldview support in the coordination of curriculum in the education system [9].

Receiving a humanitarian education, a person acquires an incentive and opportunities for the full development of his essence. The educational activity aims at enlightening a person, identifying his image in the educational process, determining the conditions for the development of physical, spiritual, moral, and mental qualities [9]. This process is based on humanitarian education, which includes a defining component of upbringing. This activity is associated with the knowledge of meaning, values, and the creation of a system of emotionalvolitional and reflexive relationships. Throughout the history of existence, Russian pedagogical culture has adhered to the principle of upbringing. Forming a person's moral core, which remains stable despite changes in external living conditions, sometimes unfavorable, has always been a priority of humanitarian education, more important than just a formal result. Observing the principle of priority of education gives opportunities to endow the subject with a positive value content, which allows reaching the top of the value level during the educational process [9].

\section{Conclusion}

In the course of media education, broad socio-cultural relations between a person and the media-cultural processes of modernity are established, and the media landscape is mastered. The main goals of media education are the development of communication methods based on non-verbal forms of communication using modern technical means and information technologies, and the language of mass media [11]. It is necessary to teach a person so that he can consciously evaluate media texts, be immune to attempts to manipulate him [12]. The humanisation of education contributes to the provision of opportunities for the personal manifestations of the learner. This means not only the demand for knowledge but also the reflection of the meaning, the value of receiving knowledge, ability to realise the purpose of understanding human nature. The humanisation of education contributes to the improvement of the individual. Humanitarian knowledge of a person in the context of profound changes in the surrounding world and the development of the media landscape should be provided considering the goals of education, value orientations, and attitudes. The problem of civilised interaction between the human being and the world of media culture is solved using humanitarian education through the development of media landscape, media education, and media reality.

\section{References}

1. V.E. Chernikova, Vestnik Stavropolskogo Gosudarstvennogo Universiteta [Bulletin of the Stavropol State University], 64, 154-159 (2009)

2. V.E. Chernikova, Gumanizatsiya obrazovaniya kak faktor preodoleniya dukhovnonravstvennogo krizisa [Humanisation of education as a factor in overcoming the spiritual and moral crisis], in A.Yu. Nagornova, M.R. Arpent'yeva, I.A. Alekseyeva (Eds.), Vysshaya shkola v Rossii i za rubezhom: problemy i ikh resheniya [Higher education in Russia and abroad: problems and solutions], 72-84 (Zebra, Ulyanovsk, 2017)

3. V.E. Chernikova, Rol' gumanisticheskikh tsennostey $v$ dukhovno-nravstvennom razvitii rossiyskoy studencheskoy molodezhi [The role of humanistic values in the spiritual and 
moral development of Russian student youth], in Sovremennost' kak filosofskaya problema: global'nyy i regional'nyy aspekt. Sbornik nauchnykh statey [Modernity as a philosophical problem: global and regional aspect. Collection of scientific articles], 66-69 (North-Caucasus Federal University, Stavropol, 2016)

4. N.Y. Efremova, The Herald of Vladivostok State University of Economics and Service, 4(17), 61-68 (2012)

5. M.A. Nosochenko, The World of Science, Culture and Education, 4(71), 77-80 (2018)

6. O. A. Stepanchuk, Gumanitarnyye znaniya v sisteme sovremennogo obrazovaniya [Humanitarian knowledge in the system of modern education], in Proceedings of the 1st Scientific International Conference "Pedagogika: Traditsii i Innovatsii [Pedagogy: Traditions and Innovations]", Volume 1, October 2011, Chelyabinsk, Russia, 24-27 (2011)

7. A.V. Merenkov, A.D. Gurarii, Izvestiya Uralskogo Federalnogo Universiteta. Obshchestvennyye Nauki [Bulletin of the Ural Federal University. Social Sciences], 12(3(167)), 90-101 (2017)

8. O.N. Zhuravleva, T.N. Polyakova, Chelovek i Obrazovaniye[Human and Education], 1(18), 9-13 (2009)

9. E.A. Elizova, Young Scientist, 4(15), 326-329 (2010)

10. S.V. Khomuttsov, Philosophy of Education, 3(24), 74-81 (2008)

11. I.V. Chelysheva, Bulletin of Chelyabinsk State University. Philology and Art History, 22 ((313)81), 254-260 (2013)

12. I.V. Chelysheva, I.A. Kozachenko-Gabrava, Bulletin of Chelyabinsk State University. Philology and Art history, 22 ((313)81), 260-266 (2013) 